\title{
PAUD Teacher Creativity in Developing Language Development Through Playing Dolls in Lempuing Sub-District
}

\author{
Yayuk Handayani ${ }^{1 *}$, Bukman Lian ${ }^{1}$, Syaiful Eddy ${ }^{1}$ \\ ${ }^{1}$ Universitas PGRI Palembang, Indonesia \\ *Corresponding author. Email: yayukhandayani611@gmail.com
}

\begin{abstract}
Creative early childhood education teachers are very critical learning influences. There are several causes, and how creativity grows and is developed, it is important to research in order to improve this creativity. Creative play games are one of the activities that can explore the competence of a person in terms of cognitive, emotional and psychomotor skills. One of them is playing with the dolls. Teacher's imagination can be turned into a game of puppets. There are several activities that can be created, including making hand puppets, telling stories using puppets, talking with dolls, creating dolls and others that can be done in teaching and learning activities at school. The qualitative approach offers an in-depth study of the formation of the imagination of teachers and an evaluation of the different factors that affect them. This practice is carried out at an early childhood education institution in the Lempuing sub-district of the district of Ogan Komering Ilir. Observation and practice are the approach used. The results of the activities show that, through developmental activities by playing with dolls, the imagination and ability of teachers to construct play activities in early childhood education can be improved, and developmental activities by playing dolls can improve children's languages.
\end{abstract}

Keywords: Imagination, Puppet Media, Creation of Language

\section{INTRODUCTION}

Developing the ability of students to become human believers According to Latuconsina in Creative Education [1] creative teachers have two definitions, namely teachers who can be creative in their lives (creative teachers) and teachers who can provide creative teaching services (creative teaching). In order to achieve a good standard of learning, the two must be synergized in a balanced way. And if not, there will be issues that interfere with the quality of learning. Modern schooling carries the fate of accountability for destructive developments in the moral and spiritual domain of humanity [2].

Successful teachers can also create high quality students [3]. To be a creative teacher, you just need to be able to teach creatively. Conversely, after we've tried to teach creatively, don't hesitate to work hard to be a creative instructor, too. Creativity is also very important in order to achieve educational objectives. 'Law No. 20 of 2003 [4], in Chapter 2, Article 3.2 states that: 'National education works to grow the ability and character and culture of a nation with integrity in the sense of improving the intellectual life of the nation, aiming at and devoting the Almighty God, possessing a noble character, health and knowledge. "Skillful, creative, independent, democratic and responsible citizens."

National growth, on the other hand, seeks to construct Indonesian society as a whole and entirely on physical and non-physical, qualitative and quantitative aspects. Quality education is thus essential to the realization of these values. Education is simply an attempt to humanize people [5].

According to Munandar, innovative and talented methods to realize creative ability and talent [6] Teacher innovation is a term that is commonly used both in schools and outside schools. People usually equate creativity with innovative goods. In other words, these creative goods are essential for the evaluation of creativity.

According to Slameto in Learning and its Shaping Factors [7] Creative understanding is basically linked to the discovery of something, of items that create something new by using something that already exists. 
From there, it means that a creative teacher is a teacher who is able to optimally upgrade and communicate all the skills that he has in order to better foster and educate students. Creative teachers would have sensitivity, initiative, creative ways of teaching, leadership and a high sense of accountability in their jobs and their roles as educators.

The teacher has an important position, therefore, because progress in the learning process is measured by the role of the teacher. Qualified teachers are believed to be able to make students think, act and act creatively [8]. In order to achieve the learning goals, teachers are often expected to be able to portray the material attractively, to choose the right media, to express the material carefully, and to use the right learning methods and strategies.

To do all this, a teacher must have a high degree of imagination. In order to create a vibrant and fun environment in the learning process, students are continually willing to learn, to be interested and to increase their knowledge.

According to Maimun [9] in Being a Teacher Who Longs for Light Who Illuminates Students' Way of Life If a teacher is more imaginative in learning, students would not encounter boredom in the following lessons. Teachers would also find it easier to build a favorable classroom environment. In fact, that is an essential function in the life of teachers for students, so that teachers are missed by students in the classroom.

According to Abdul Hadith in Psychology in Education [10] the success or failure of learning also depends on the ability of the student to master the subject. Learning results will last a long time if, by penetrating the child's personality, the learning content is well interpreted and what is being learned has a real significance for the student's life. Interaction in classroom learning can have an effect on the quality of the process and on learning outcomes in the classroom at the micro level and can potentially enhance the quality of education at the educational institution level as well as the quality of education at the macro level.

Thus, education really wants a teacher to equip himself with the different abilities that are supposed to support and direct him in the performance of his duties. In the learning process, the teacher is the person who gives the lecture, and the student is the person who receives the lesson.

Awareness, expertise or skills as a teacher are required for the transfer of knowledge to students. Strong innovation is expected to encourage the moral growth of students and to achieve national educational objectives related to experience and to make human beings who are whole and who strive, namely, to have good achievements.
To examine the learning process, the emphasis is on the question of how teachers provide opportunities for students to provide a successful learning process with a view to achieving outcomes in line with predetermined objectives.

The most important thing in the learning process, according to Ainun Ilham in Learning Objectives (2014), is the purpose of the process, namely how to achieve predetermined learning. To assess the level of student achievement in acquiring knowledge or content, it can be seen from student achievement, both of which cannot be differentiated from student motivation and teacher imagination in teaching. The Play Group in the Lempuing District is the place used as a study center. The reason the researcher chose this position was because, based on the results of previous observations, the researcher noticed that many students in this school seemed oblivious to the explanations provided by the instructor.

Creativity, then, is the ability to convey and realize potential thinking capacity to create something new and special, or the ability to combine something that already exists into something else to make it more desirable. Creativity may also be defined as the ability to create a new product or the ability to deliver new ideas and to apply them to problem-solving. Teachers must compete in learning by ensuring easy learning for all students so that they can optimally grow their potential. Learning is a dynamic process and includes a number of interrelated aspects. Therefore, 'to create creative and fun learning, skills are required, like learning skills or teaching skills. In order to create creative, skilled and fun learning, it is important to have skills that must be possessed and mastered by teachers, Turney said in Mulyasa's book [11].

There are 8 teaching skills that play a key role and decide the level of learning, namely the ability to ask questions, to provide reinforcement, to differ, to explain, to open and close lessons, to lead small group discussions, to manage classes and to teach small groups and individually.

Conduct the variations listed above, namely variations in learning practices such as the use of learning methods and media. Thus, in fact, "creativity is a skill, meaning that anyone who intends to be creative and wants to do the right exercises will be creative "Creativity is defined by the presence of "the activity of creating something that was not there and not done by someone or a tendency to create something". Education has a role and a strategic role to play in producing children's creativity [12].

In the learning process, therefore, an instructor must be imaginative in order to always create a fun learning environment so that students do not feel bored and encounter learning difficulties. The management of a 
successful teaching and learning process, assisted by the imagination of students, would thus be able to achieve the desired objectives.

\section{METHODS}

Sampling was carried out using purposive sampling technique; The researcher decides the parameters regarding which respondents can be chosen as samples. According to Arikunto [13], the sampling technique is not focused on random, geographic or strata, but is based on factors that concentrate on certain objectives. This means sampling on the basis of such factors, such as the characteristics of the population or previously established characteristics. In the meantime, Sugiyono [14] is a technique for the determination of test samples with certain considerations that seek to make the data collected more representative.

The subjects of this research were all play group teachers in the district of Lempuing. Collection of data using observation methods and direct interviews with many teachers in the Lempuing district.

\section{RESULTS AND DISCUSSION}

This research began with direct visits to the research subjects, which were teachers who carried out teaching and learning activities in the play group of the Lempuing district, including the play group of Bunda II in the village of Pandan Area, the play group of Nurul Hidayatullah, the village of Pandan, the play group of Wika Pertiwi Cahya Bumi, and the Terate II Tugumulyo play party, from a variety of observations and interviews, the researcher found items that could be communicated about the imagination of the instructor. Among them, there are:

1. In Wika Pertiwi Cahya Bumi's language development group, teachers do not show strong imagination, so children feel bored and uninterested. The teacher does not prepare an activity plan before teaching and learning activities, the teacher does activities in the classroom, but uses student worksheets only, so the children feel like they still have to carry out assignments from the teacher. Learning to read, write and find out is a regular task for children that they can enjoy later as they reach elementary school age. By memorizing letters and numbers, children can, but conceptually, children do not understand numbers and letters, and even in terms of spoken language, children may not meet the requirements of being able to do so.

2. In the play group Nurul Hidayatullah Kota Pandan and Terate II Tugumulyo, the teacher does not use interesting media and uses student worksheets only modestly. So that children know that they only have a job to perform and do not show imagination either.
Both children are concentrated on the teacher's mission only, and in developing the child's language, the teacher does not encourage the child's environment, that is, the world of play, so that the repetition of the teacher's assignments always makes children feel exhausted and unattractive in their view. The teacher also displays less imagination in different tasks.

3. There is 1 instructor showing imagination, namely in Bunda 2 Pandan City, using puppet media to build a child's language. In this game, where the children are very excited and willing to engage in the activities of talking and playing with dolls, the children are happy and come out of the different vocabularies that are very provocative of the children's language, from the observations of the author, how happy the children are to play with hand puppets, the children play a role in talking and laughing. From the start of welcoming and perceptual exercises in teaching, the teacher has planned it well, the language learning scenario has also been set out in the regular activity plan, from the start of development activities to the end of the activity, it is very clear that children are very happy to take part in doll play activities, there are some children who do. That is, the instructor is positioning himself as a friendly facilitator. Some of the above observations demonstrate the positive side of a creative instructor, namely openness to the environment, including 1) freedom to see the environment/act; 2) a deep dedication to change and success; an optimist and willing to take risks, including the worst risks; patience in practice; challenges; an environment that is conducive, not rigid, and authoritative.

In relation to Alhuasainil's study [15], on the impact of work motivation and work discipline on the performance of teachers, the findings of this research show that there is a significant effect of work motivation on the performance of teachers, and that there is a significant influence of discipline. Work on teacher performance, there is a major impact on teacher performance between work motivation and work discipline.

Anggraini [17] has published another similar research in the PGRI private university community service journal PAUD Teacher Innovation in the creation of bilingual literacy through social media blogs in the Limo and Cinere sub-districts. The findings of this study indicate that community service programs show that through social media, blogs can improve the imagination of teachers and the bilingual literacy skills of PAUD teachers.

Of the many studies above, of course, this author's study has the same relationship, i.e., teacher discipline, teacher courage, hard work, and teachers who are 
always learners who, of course, often try new positive stuff, have made a significant contribution to the growth of the imagination of both teachers. Nor children, either.

In the meantime, the authors have established a variety of different topics that the authors of course need to communicate, as the author's research has identified holes that emerge from several causes, namely: 1) lack of government attention to the welfare of early childhood teachers so that teachers do not have time to display ingenuity, and 2) in addition, the researcher also noticed that there was no assurance about their profession as a PAUD teacher from many interviews with the students, so that many teachers only taught modestly and as required.

\section{CONCLUSION}

From the author's point of view, imaginative teachers really evaluate children's imagination and also help to improve children's language. This, in turn, fosters children's interest in learning, particularly in early childhood language. Learning is enjoyable at the child's level of skill. In the meantime, less innovative teachers also have the ability to hinder children's imagination, since they do not promote children's learning individuality.

\section{ACKNOWLEDGMENTS}

Thank you very much to the Principal and Teacher Board of PAUD in Lembuing Sub-District. It was also forwarded to the Chancellor, Postgraduate Director, Head of Education Management Study Program, Advisor I, Supervisor II and all postgraduate lecturers at PGRI Palembang University. Also, for all fellow graduate students of PGRI Palembang University. Thank you for helping to complete this journal, which is the result of the preparation of the thesis as a prerequisite for the final report. Please criticize and recommend to develop this journal.

\section{REFERENCES}

[1] Latuconsina (2014). Pendidikan Kreatif [Creative Education]. Jakarta: PT Gramedia Puataka Utama

[2] Maseleno, A., Ayshwary, B., Ivanova, T. N., Hashim, W., Nguyen, P. T., Shankar, K., Kristiawan, M., Huda, M. (2019). General Theoretical and Philosophical Aspects of Modern Education. Aspectos Teóricos y Filosóficos Generales de la Educación Moderna. Revista San Gregorio 2019, No. 32 Special Issues August.

[3] Hanim, H., \& Rahmadoni, J. (2020). Determination of Lecturer Reception Using Analytical Hierarchy Process (AHP). Journal of Applied Engineering and Technological Science (JAETS), 1 (2), 136 141.

[4] Undang-undang No. 20 tahun 2003, Kementerian Pendidikan Nasional. (2003). Undang-undang Nomor 20 Tahun 2003 tentang Sistem Pendidikan Nasional [Law Number 20 of 2003 concerning the National Education System]. Jakarta: Kementerian Pendidikan Nasional.

[5] Wandasari, Y., Kristiawan, M., \& Arafat, Y. (2019). Policy Evaluation of School's Literacy Movement on Improving Discipline of State High School Students. International Journal of Scientific \& Technology Research 8(4).

[6] Munandar, U. (2002). Kreativitas dan keberbakatan Strategi mewujudkan Potensi Kreatif dan Bakat [Creativity and giftedness Strategies to Realize Creative Potentials and Talents]. Jakarta:Gramedia Utama.

[7] Slameto. (1995). Belajar dan Faktor Yang Mempengaruhinya [Learning and its Influencing Factors]. Jakarta: Rineka Cipta.

[8] Ruslan, Lian, B., \& Fitria, H. (2020). The Influence of Principal's Situational Leadership and Teacher's Professionalism on Teacher's Performance. International Journal of Progressive Sciences and Technologies (IJPSAT), 20(1). Retrieved from https://ijpsat.ijshtjournals.org/index.php/ijpsat/article/view/1733

[9] Maimun (2014). Menjadi Guru Yang Dirindukan Pelita yang Menerangi Jalan Hidup Siswa [Becomes the Teacher Missed by the Light who Illuminates the Way of Life of Students]. Solo: Ziyad vizi

[10] Hadith, A. (2008). Psikologi Dalam Pendidikan [Psychology in Education].. Jakarta:Universitas Terbuka.

[11] Mulyasa. (2013). Menjadi Guru Profesional Menciptakan Pembelajaran Kreatif dan Menyenangkan [Becoming a Professional Teacher Creates Creative and Fun Learning]. Bandung: PT Remaja Rosdakarya.

[12] Lian, B., Kristiawan, M., \& Fitriya, R. (2018). Giving Creativity Room to Students Through the Friendly School's Program. International Journal of Scientific \& Technology Research Volume 7, Issue 7. Retrieved from https://www.ijstr.org/finalprint/july2018/Giving-Creativity-Room-ToStudents-Through-The-Friendly-SchoolsProgram.pdf 
[13] Arikunto, S. (2010). Prosedur penelitian suatu pendekatan praktik [The research procedure is a practical approach]. Jakarta: Rineka Cipta

[14] Sugiyono. (2010). Metode Penelitian Pendidikan Pendekatan Kuantitatif, Kualitatif, dan $R \& D$ [Educational Research Methods with Quantitative Approaches, Qualitative, and $R \& D]$. Bandung: CV Alfabeta.

[15] Alhusaini, A., Kristiawan, M., \& Eddy, S. (2020). Pengaruh Motivasi Kerja dan Disiplin Kerja terhadap Kinerja Guru [The Effect of Work Motivation and Work Discipline on Teacher Performance]. Jurnal Pendidikan Tambusai, 4(3), 2166-2172. Retrieved from https://jptam.org/index.php/jptam/article/view/693

[16] Rahmatika, D. F., \& Ratnasari, N. (2018). Media Pembelajaran Matematika Bilingual Berbasis Sparkol Videoscribe [Bilingual Mathematics Learning Media Based on Videoscribe Sparkol]. Desimal: Jurnal Matematika, 1(3), 385393.

[17] Anggraeni. (2018). Kreativitas Guru Paud Dalam Mengembangkan Literasi Dwi Bahasa Melalui Media Sosial Blog Di Kecamatan Limo Dan Cinere. E-Dimas. Jurnal PEngabdian Kepada Masyarakat vol 9 (2). 